WOODLAND BIRDS PROCEEDINGS 


\title{
Woodland birds in patchy landscapes: the evidence base for strategic networks
}

\author{
P.M. DOLMAN ${ }^{1}$, S. A. HINSLEY ${ }^{2}$, P. E. BELLAMY ${ }^{2}$, K. WATTS $^{3}$ \\ ${ }^{1}$ School of Environmental Sciences, University of East Anglia, Norwich NR4 7TJ, UK \\ ${ }^{2}$ Centre for Ecology and Hydrology, Monks Wood, Abbots Ripton, Huntingdon, Cambridgeshire PE28 \\ 2LS, UK \\ ${ }^{3}$ Forest Research, Alice Holt Lodge, Farnham, Surrey GU10 4LH, UK
}

\section{Running title: Woodland birds in patchy landscapes}

Habitat creation and management within wooded networks is a potentially effective strategy to reduce ecological isolation and deleterious effects of fragmentation. However, questions remain over the relative advantages of different approaches; for example buffering patches versus increasing connectivity. Potential effects of woodland fragmentation include reduction in regional woodland cover, reduced patch size, edge effects with loss of core habitat, and increased isolation with disruption of dispersal and metapopulation dynamics. We adopt an evidence-based approach to review how each of these affects woodland birds with an emphasis on studies from the UK and use this to identify management priorities for mitigation. There is evidence for both patch area and composition effects: larger woodlands support more woodland bird species and woods located within sparsely wooded landscapes are less valuable to specialist woodland species. Bird assemblages show a nested pattern with respect to area, thus species found in small woods also occur in large woods but not vice versa. However, small woods may be preferred by a few edge species, while small woods also have greater variability in bird species composition. Consideration of the metapopulation dynamics of specialist species with poor dispersal shows that creating or buffering large woodlands is more efficient than a greater total area of small fragments. Connectivity appears most useful for widespread generalist species with almost continuous populations. Woodland structure and quality are of overwhelming importance: as well as mature woodland, young growth, scrub and edges are also key components. There is an urgent need to examine the relationship between nest predation and landscape structure within UK woodlands.

Keywords: habitat fragmentation, wooded networks, landscape restoration, dispersal, metapopulation. 
Many different factors potentially contribute to recent changes in the abundance and distribution of woodland birds (Amar \& Hewson this issue). Within woodlands, habitat quality and structure are of major importance, but in this paper we examine the extent to which landscape structure is also important when planning strategies for the conservation of woodland birds.

Britain has a low proportion of woodland cover and that which remains is highly fragmented. Elsewhere, such fragmentation is considered to be a serious threat to biodiversity value (Tilman et al. 1994, Saccheri et al. 1998, Hanski \& Ovaskainen 2000). In the UK, extensive woodland loss and fragmentation had taken place a millennia ago (Rackham 1986) so that contemporary conservation may be starting from a position where loss of species with large-area requirements and evolutionary adaptation of remaining species has already occurred. Functional isolation has increased with intensification and simplification of the agricultural matrix since the mid part of the $20^{\text {th }}$ Century. More encouragingly, the extent of woodland cover is now increasing (Mason, this issue), while agrienvironment measures can be used to improve connectivity and reduce functional isolation. There are initiatives to recreate woodland networks, to combat ecological isolation in a targeted fashion without the need for large-scale expansion of woodland ( Peterken et al. 1995, Hampson \& Peterken 1998, Peterken 2000 \& 2003). Spatial prioritisation of woodland creation and habitat mitigation are increasingly based on consideration of landscape structure and land cover thresholds (Peterken 2002, Woodland Trust 2002). Taking this approach further, the new ancient woodland policy for England (Forestry Commission 2005) aims to create opportunities to develop networks of woodland and other semi-natural habitats into ecologically functional landscapes.

This raises important questions as to how best to prioritise the addition of new woodland within the landscape. What are the best configurations for key species and which existing landscapes should be targeted? Metapopulation dynamics are often assumed to be important, leading to a set of prescriptions that emphasise connectivity (Harrison 1994), which have consequently been adopted as planning guidance for woodlands (Defra 2006). However, the relevance of metapopulation principles to the colonisation and persistence of woodland species has been challenged (Dolman \& Fuller 2003). Renewed attention to the detrimental edge effects and the importance of core areas places emphasis on buffering existing woodlands (Dolman \& Fuller 2003). In evaluating priorities it is vital that strategic policy and conservation prescriptions are based on available evidence, rather than assumptions and cultural trends (Sutherland et al. 2004). This is especially true for woodland creation in which decisions taken now constrain opportunities in the future, while created woodland can take decades or even centuries for its habitat quality to develop.

Mapping, modelling and decision support tools are now available to analyse meta-population and connectivity networks (Reijnen et al. 1995). For example, least-cost analysis tools (Adriaensen et al. 2003, Chardon et al. 2003) within BEETLE (Biological and Environmental Evaluation Tools for Landscape Ecology) have been used by Forest Research to analyse potential woodland networks in 
Wales and Scotland to aid the targeting of woodland conservation action (Watts et al. 2005a, Watts et al. 2005b). Using remotely sensed and field habitat data, such as Centre for Ecology and Hydrology (CEH) Land Cover 2000 data (Haines-Young et al. 2000), Countryside Council for Wales (CCW) Phase 1 survey (Day 1989, Howe \& Blackstock 1991) and Ancient Woodland Inventory (CCW, unpublished data), it is possible to define and map patches of woodland and also to analyse the composition of the matrix (Fig. 1a, b). By making assumptions about the ecological cost of dispersal of generic species in different matrix habitats a cost surface for dispersal can be produced (Fig. 1c). Combining these in a given landscape allows potential connectivity networks to be defined (Fig. 1d). Clearly, in any given landscape, the outcome of such modelling depends on assumptions about dispersal ability and costs. Woodland networks defined for species with specialist requirements and limited dispersal ability are greatly restricted with less connectivity, than the broader networks defined for more generalist species with good dispersal ability (Watts et al. 2005a).

In the UK, such woodland network analyses have largely been conducted using generic species, with dispersal characteristics defined primarily in relation to woodland invertebrates or plants. But what are the dispersal abilities of woodland birds; is there evidence that woodland created within a network is more likely to be colonised, or can some species readily disperse between networks? Crucially, if new woodland is to be created within such networks, where and how should it be located for example joining and buffering existing fragments, or placed as a stepping stone between fragments?

In the remainder of this paper we consider how landscape structure affects community and population processes of species richness, colonisation, local abundance, productivity, persistence and probability of local extinction. We review empirical evidence for the importance of mechanisms and draw conclusions for the restoration of wooded landscapes.

\section{EFFECTS OF LANDSCAPE COMPOSITION AND CONFIGURATION}

Once extensive woodland cover has been reduced to numerous fragments. This fragmentation affects both landscape composition (the relative amount of different habitats) but also the configuration, or spatial arrangement, of the woodland remaining (Wiens 1994). Composition is important to woodland birds both in terms of the extent of woodland within a landscape and also the composition and permeability of the matrix, with consequences for ecological isolation. The configuration of woodland patches has consequences for patch size, the ratio of edge to interior, the proximity or isolation of patches from sources of colonists and the juxtaposition or contagion of landscape elements (Dolman \& Fuller 2003, Dunning et al. 1992). Both the composition of landuse and habitats within the matrix and their configuration relative to woodland fragments can affect the intensity of edge effects.

Woodlands can be considered as homogenous patches in a heterogeneous landscape, but this is a simplification as individual woods are also 'patchy' containing areas of open habitat and stands that differ in age, structure or species composition. Studies of landscape ecology often focus on the larger of these scales but neglect the second. Clearly the size and arrangement of individual woodland patches 
within the landscape can be important for population processes of dispersal, colonisation and local extinction. However, the spatial arrangement of habitat elements within woodlands can affect individual foraging and provisioning behaviour and the suitability of woodland habitats. Therefore we give some attention to effects of landscape heterogeneity within woodlands, as well as the arrangement of woodlands within the wider landscape.

\section{Effects of Landscape Composition}

Metapopulation theory predicts that regional population abundance may affect local abundance (Hanski 1999) and such relationships between regional and local abundance have been found in studies of birds (Andrén 1994, Villard et al. 1999). When loss of suitable woodland patches exceeds a threshold, lack of sufficient immigrants to remaining patches is predicted to cause metapopulation collapse and regional extinction (Hanski 1998). Evidence for this is provided by a Spatially Explicit Population Model (SEPM) of a Wood Nuthatch Sitta europaea metapopulation within a sparsely wooded landscape $(20 \mathrm{~km} \times 20 \mathrm{~km}$; c. $4 \%$ woodland cover) in Cambridgeshire (Alderman et al. 2005). Population size in wood fragments increases with increasing numbers of immigrants from an adjacent more heavily wooded source landscape, but below a threshold of $c .10$ immigrants per year the simulated population collapses (Alderman et al. 2005). The model predicts that observed numbers within the study area could only be maintained with an immigration rate of 10-15 individuals per year. However, within-patch habitat quality is also important, improving this lowered the immigration threshold above which the simulated Wood Nuthatch population became self-sustaining (Alderman et al. 2005). Earlier empirical models of Wood Nuthatch that considered habitat quality and local landscape structure (area of suitable habitat within a $3 \mathrm{~km}$ radius of the focal wood) but that did not incorporate individual dispersal, predicted higher numbers than were observed in this landscape, leading Bellamy et al. (1998) to conclude that isolation was a problem for this population.

In a study of fragmented woodland $(n=16)$ in a sparsely wooded region of North Humberside, England (mean $2.6 \%$ woodland cover) species richness of woodland birds was most strongly related to the distance of the wood to the boundary of a 'wooded archipelago' (defined as $>4 \%$ woodland cover), and less strongly to characteristics of the woodlands themselves (McCollin 1993). This is consistent with reduced colonisation of woodland patches located in that part of the landscape with a lower proportion of woodland cover $(<2 \%)$.

For Western Capercaillie Tetrao urogallus, that requires large areas of old boreal forest for individual territories (e.g. 20-50 ha) and much larger areas for a lek (e.g. 200-500 ha: Anglestam 1992) the effects of reducing the proportion of old forest within the landscape are complex and vary depending on the scale of landscape grain (Rolstad \& Wegge 1987). Analysis of two contrasting landscapes in Norway suggests that, when loss of old forest is low or moderate, then the density of leks may be higher if the landscape is relatively fine-grained, comprising small clear-cuts among a matrix of old forest and a high density of internal edges. In contrast, when old forest cover is reduced to less than fifty percent of 
the landscape, then density of males is higher if the mosaic is course-grained, so that individual patches are large enough to support a lek (Rolstad \& Wegge 1987). However, the viability of woodland grouse populations may be further compromised in fragmented landscapes, due to proximity of remaining old forest patches to open habitats that are a source of intruding generalist predators (Anglestam 1992). This is supported by evidence from Finland, where for both Western Capercaillie and Black Grouse $T$. tetrix, the proportion of post-breeding females accompanied by broods was lower in heavily fragmented than in more continuous forest landscapes (Kurki et al. 2000). Here landscape effects were strongest at a scale of approximately $100 \mathrm{~km}^{2}$, much larger than the size of family home ranges, and were interpreted as being due to higher nest predation by generalist predators in fragmented landscapes rather than local effects such as distance to edge.

Although species occurrence, composition and richness is primarily determined by characteristics of the woodland itself, at both local and regional scales the species richness of migrant woodland birds may also be affected by the amount of woodland within the landscape ( Hinsley et al. 1998, Bennett et al. 2004). Within a sparsely wooded region of Eastern England, the species richness of migrant woodland birds is greater in woods ( $n=88$, size range: $0.5-29.9$ ha) with a greater area of woodland and length of hedge within $1 \mathrm{~km}$, as well as depending on characteristics of the woods themselves (area, perimeter) (Bennett et al. 2004). At a wider scale, the total number of migrant species recorded in replicate small woods within each of six study areas (three in the UK, one each in the Netherlands, Denmark, and Norway), increased with increasing percentage woodland cover in the study areas (Hinsley et al. 1998).

The extent of woodland within the landscape is clearly important and landscapes with a greater proportion of woodland cover are of greater value. But to what extent does the arrangement of that woodland matter?

\section{Effects of woodland size}

Woodland area is generally the most important predictor of species occupancy, richness, composition and turnover (Bennett et al. 2004). In eastern England, larger woods contain more species (Bellamy et al. 1996a) (Fig. 2a). However, the increase in species number is largely due to a rapid increase in very small woods (e.g. from 0.1 to 3 ha), followed by a progressive, but slower, increase up to 10 ha.

Absolute turnover (the number of extinctions or gains of species within individual woods between consecutive years) is similar across the range of woodland size (Hinsley et al. 1995)(Fig. 2b), though in smaller woods this represents a larger proportion of the species present. In 145 small woods censused over three years, the probability of extinction was universally lower in larger woods or woods with more breeding pairs, for all eight common species analysed: Winter Wren Troglodytes troglodytes, European Robin Erithacus rubecula, Hedge Accentor Prunella modularis, Blue Tit Cyanistes caeruleus, Great Tit Parus major, Chaffinch Fringilla coelebs, Common Blackbird Turdus merula and Song Thrush Turdus philomelos (Bellamy et al. 1996b). For Long-tailed Tit Aegithalos caudatus, some stochastic 
extinction occurred even in woods up to 10 ha. However, few or no area effects were found for species colonisation. As a consequence of species turnover, the species composition of smaller woods is less predictable, with greater heterogeneity among woods.

The species contributing to turnover are those with small population sizes and thus differ between large and small woods (Table 1). In small woods colonisation / extinction is by common and ubiquitous species, while in larger woods, where population sizes of these common species are larger, other more woodland-dependent species, occurring in lower numbers and usually absent from smaller woods, contribute to turnover. Therefore, species occurrence shows a nested pattern. Woodland birds differ in their area thresholds for breeding (Fig. 3). In general, species with less specific habitat requirements such as Common Blackbird and European Robin (also Chaffinch, Blue Tit and Winter Wren) occur in most woods including those of 1 ha and less. Other species, such as Eurasian Treecreeper Certhia familiaris and Marsh Tit Poecile palustris (also Common Chiffchaff Phylloscopus collybita, Long-tailed Tit and Great Spotted Woodpecker Dendrocopos major) only approach $100 \%$ occurrence in woods of 10 ha or more. These are species usually considered to be dependent on woodland and are less common or absent from secondary habitats (such as hedgerows and gardens).

The intensive studies in Cambridgeshire took place in a sparsely wooded landscape $(<2 \%$ cover) with many extremely small woodland fragments and few large woodlands. In landscapes that retain a greater proportion of woodland cover and larger maximum woodland area, species with more exacting area requirements may persist, so that further accumulation of woodland species may be expected beyond the 10 ha threshold of the Cambridgeshire study. In the study of 16 woodlands in North Humberside overall species richness increased with woodland area (McCollin 1993). However, for a group of ubiquitous species (including Great Tit, Blue Tit, European Robin, Winter Wren, Common Blackbird, Hedge Accentor, Chaffinch, but also Song Thrush, Blackcap Sylvia atricapilla, Spotted Flycatcher Muscicapa striata and Willow Warbler Phylloscopus trochilus) richness reached an asymptote at less than 10 ha, while for a group of 'woodland' species (including Common Redstart Phoenicurus phoenicurus, Hawfinch Coccothraustes coccothraustes, Great Spotted Woodpecker, Tree Pipit Anthus trivialus, Eurasian Treecreeper, Long-tailed Tit, Coal Tit Periparus ater and Marsh Tit) species accumulation continued beyond 10 ha (McCollin 1993).

In a study of 165 pine dominated forests in Poland ranging in area from 0.01 ha - 282 ha (including 15 forests of $10-30$ ha and $14>30$ ha), species richness again increased with increasing area, as well as being influenced by structural (number of age classes represented) and biological (number of tree species) diversity (Cieslak 1985). A number of generalist and edge species approached maximal levels of occupancy in woods $<3$ ha (e.g. Yellowhammer Emberiza citrinella, Chaffinch, Common Chiffchaff), or $<10$ ha (Willow Warbler, Tree Pipit, Wood Warbler Phylloscopus sibilatrix, Icterine Warbler Hippolais icterina, European Robin), while others only approached maximum frequency in woods $>10$ ha (e.g. Common Blackbird, Willow Tit Poecile montanus, Crested Tit Lophophanes cristatus, Winter Wren, Spotted Flycatcher, Pied Flycatcher Ficedula hypoleuca, Blackcap) or $>30$ ha (e.g. Wood Lark Lullula arborea, Hawfinch, Goldcrest Regulus regulus, Short-toed Treecreeper Certhia 
brachydactyla) (Cieslak, 1985). A number of species were absent from woods of 10 ha or less (e.g. Northern Goshawk Accipiter gentilis, Red-breasted Flycatcher Ficedula parva, Mistle Thrush Turdus viscivorus). In this study region species accumulation clearly continues beyond the range of areas considered in the Cambridgeshire and Humberside studies. However, it is also important to note the very different landscape associations of some species, such as Common Blackbird, European Robin and Winter Wren, that responded positively to increasing forest area in Poland but are ubiquitous or edge species in England. The high incidence of 'edge-adapted' species within the British avifauna is further emphasised by comparison with the Netherlands: although Common Blackbird, Winter Wren and Great Tit had high probability of occurrence in small woods, as they did in England, Hedge Accentor only reached maximal incidence in woods larger than 5 ha (van Dorp \& Opdam 1987).

The nested pattern of species occurrence and turnover with a greater number of woodland specialists breeding in larger woods, suggests a strategy of targeted woodland creation in large woodland blocks, or additional buffering of larger in preference to smaller woodlands. However, as habitat quality and species density may vary with woodland size, it is important to identify any species for which small woods are more suitable. Counter-intuitively, a number of woodland species occur at higher densities in smaller woods. Bellamy et al. (2000) analysed species abundance data from annual censuses of 53-160 woods (up to 10 ha) over eight years, by fitting a power function of the form:

Abundance $=a .(\text { Area })^{b}$

Where $a$ is a scaling parameter and $b$ describes the relationship between abundance and area. When $b$ is equal to one then abundance is proportional to area (i.e. density is constant). For Long-tailed Tit, although a mean slope of 1.3 (Table 2) is suggestive of higher proportionate abundance in larger woods, $b$ did not differ significantly from 1.0 in six of the eight years (Bellamy et al. 2000). Conversely, if the slope of the power function is less than one then density is higher in smaller woods. Of eight species tested, seven tended to have higher densities in smaller woods (Bellamy et al. 2000) (Table 2).

For both Hedge Accentor and Common Blackbird, the estimate of the slope was significantly less than one in every one of the eight years (Bellamy et al. 2000). Furthermore, both Hedge Accentor and Common Blackbird had lower numbers in large woods in those years with a lower regional population, suggesting small woods are preferentially settled and that large woods may be suboptimal for these species. Preference of Hedge Accentor and Common Blackbird for smaller woods and woodland edges has been related to their use of adjacent open habitat for foraging (Bellamy et al. 2000, Hinsley et al. 1995). For Chaffinch, the slope was also less than 1.0 in all eight years. For Blue Tit, Winter Wren, Great Tit and European Robin, results were also indicative of higher density in smaller woods. However, in contrast to Common Blackbird and Hedge Accentor, for Chaffinch, Blue Tit, Great Tit, and European Robin numbers were lower in small woods in years with a lower regional population levels. This suggests that, even though higher densities were found in smaller woods, these woods may be sub-optimal and a buffer effect may be operating. Evidence for this is available for Blue and Great 
Tit, which have a lower reproductive output in smaller woods in Cambridgeshire (Table 3) (Hinsley et al. 1999). Furthermore, in Oxfordshire there is evidence of phenotypic quality-dependent dispersal of Great Tits from farmland into better quality woodland breeding habitat (Riddington \& Gosler 1995), identified by preferential settlement in the woodland by individuals with greater body mass as nestlings (Verhulst et al. 1997).

In conclusion, large woods are again found to be preferable for most species. However, for some edge and supplementing species such as Common Blackbird and Hedge Accentor, small woods are preferable. Within a region, heterogeneity of wood size may therefore be useful.

So far we have considered the effects of woodland area in terms of individual woodlands. However, it is also important to consider the size of individual woods within woodland networks. The SEPM of (Alderman et al. 2005) considers the Wood Nuthatch, a poorly dispersing woodland habitatspecialist. The model was used to evaluate different scenarios of strategic woodland habitat creation. The current landscape in the Cambridgeshire study area, comprising small patches totalling 298 ha of suitable habitat, cannot sustain a viable population in the absence of immigration. Targeting woodland creation to buffer large core areas sustains the population and even adding just 40-60 ha of new woodland adjoining the one largest wood makes the population viable (Table 4). However, adding a much greater area of habitat dispersed across all small woods failed to make the meta-population selfsustaining. This demonstrates, for this species at least, the strategic importance of large 'mainland' or source patches, with larger local population size, lower chance of stochastic extinction and that therefore favour metapopulation viability (Hanski et al. 1996). This finding is emphasised in the 'key patch' approach to network analysis adopted by Verboom et al. (2001). For two generic bird species with contrasting area requirements and dispersal abilities modelled within a habitat network, the total area of habitat required to sustain a viable population was again much less if the network included a "key patch", defined as a single patch large enough to sustain a population with only minimal immigration (Verboom et al. 2001). Reviewing avian time-series data from a range of studies Verboom et al. (2001) found that a minimum population of $12-25$ pairs within a single patch were required for local population persistence.

\section{Dispersal in complex landscapes - proximity, isolation and connectivity}

The crucial importance of one or more core woodlands to the viability of the Wood Nuthatch metapopulation is a result of the limited dispersal ability of this species, which is thought to have a high mortality during dispersal. A contrasting species with good dispersal ability and negligible mortality risk from natal dispersal should be able to sustain a metapopulation across a fragmented network comprising only small patches. It is, therefore, important to understand how representative the Wood Nuthatch is relative to the dispersal abilities of other woodland birds. 
Dispersal distances of birds breeding in the UK are typically a few $\mathrm{km}$ (Paradis et al. 1998). The Wood Nuthatch, although amongst the poorer dispersing woodland species (Fig. 4) is not atypical. Migrants generally disperse further than residents (Paradis et al. 1998) and among the 28 species of woodland birds considered in Fig. 4, the three species with the greatest mean dispersal distances are Blackcap, Common Chiffchaff and Pied Flycatcher. Larger birds also disperse further (Paradis et al. 1998) and the next greatest distances are shown by Great Spotted Woodpecker and Eurasian Sparrowhawk Accipiter nisus. Contrary to theoretical expectations (Laurance 1991), more abundant species disperse shorter distances (Paradis et al. 1998). Although the Wood Nuthatch appears to be a classically dispersal limited species, the two species with lowest dispersal amongst the 28 considered here are Hedge Accentor and Chaffinch.

Dispersal has important consequences for the spatial structuring of populations, and a positive correlation between dispersal ability and population synchrony has been widely predicted in the theoretical literature. This was confirmed by an analysis of 53 British bird species; the strength of local population synchrony (mean of cross-correlations between pairs of census sites, after controlling for inter-year trends) was greater in species with greater mean dispersal distance (Paradis et al. 1999). In addition, population heterogeneity (variance in local abundance) was greater in species with lower mean natal dispersal (Paradis et al. 1998).

At the more local scale of the Cambridgeshire study region, population synchrony of woodland birds is related to distance between woods and also to characteristics of the wider landscape (Bellamy et al. 2003). Of 13 species tested eight showed a decline in (global) population synchrony with increasing distance between woods (Bellamy et al. 2003). However, only two remain significant (Hedge Accentor, Long-tailed Tit) after Bonferoni correction to control the type-1 error rate across the multiple Mantel tests. For three species (Winter Wren, Long-tailed Tit, Hedge Accentor) there was evidence that the decline in synchrony between pairs of woodlands at greater distances might have been due to limited dispersal: a relationship between synchrony and distance was found within the scale of natal dispersal, but not at greater distances. That only three of the 11 species had evidence for dispersal causing a decline in synchrony with distance, suggested that dispersal is not a general driver of synchrony at this scale. For two of these (Winter Wren, Hedge Accentor) and also for Blackcap, local synchrony was negatively related to distance between woods within wooded landscapes but not in open landscapes, suggesting a role of landscape structure in dispersal and synchrony (Bellamy et al. 2003). For Common Blackbird and Hedge Accentor, within a scale of $20 \mathrm{~km}$, local synchrony was related to distance between woods and also to the difference in the amount of hedge around the wood. Woods with little connectivity had similar synchrony, woods with more connectivity were also similar in the timing of population change, but woods with good connectivity fluctuated out of step with unconnected woods. These are extinction prone species and the results can be interpreted as a lag in recolonisation after local extinction in more isolated woods (Bellamy et al. 2003). Simultaneously testing distance between woods, hedgerow and woodland cover showed that hedgerow was more important than the 
regional extent of woodland cover in explaining synchrony for Hedge Accentor, Blackcap and Common Blackbird (Bellamy et al. 2003).

Synchrony has been interpreted as indicative of greater metapopulation vulnerability and hence, by inference, as a potentially negative effect (Bellamy et al. 2003). However, we argue the opposite interpretation, that synchrony among fragmented woodland bird populations indicates good connectivity, the potential for rescue effects and rapid recolonisation of vacant fragments, and thus reduced regional vulnerability. In classic metapopulation theory, long term persistence occurs because asynchrony among local populations reduces the risk of overall metapopulation extinction. In spatially explicit metapopulation models with area-dependent extinction and isolation-dependent colonisation probabilities, 'regional stochasticity' (where patches within a region experience synchronous variation in local extinction or colonisation rates) increases the chance of metapopulation extinction, even in landscapes with more and better connected habitat patches (Hanski 1998). Similarly, other theoretical treatments also predict that synchrony among spatially structured populations connected by dispersal increases the likelihood of global extinction (Allen et al. 1993; Heino et al. 1997). However, Paradis et al. (1999), Paradis et al. (2002) and Bellamy et al. (2003) first remove regional or national population trends between years, that result from environmental change or weather effects throughout extensive regions (i.e. the 'regional stochasticity' of Hanski), before examining the 'local synchrony' in residual population variation among sites. Thus in the study system of Bellamy et al. (2003) synchronous changes in population size was due to weather, while local asynchrony could arise from delayed recovery following local extinction or reduction. Local asynchrony in bird populations may therefore be viewed as a symptom of a landscape with impeded dispersal that increases global population vulnerability.

For Blue Tit, the probability of breeding is higher in small woods with a greater amount of hedgerow in the surrounding landscape (Hinsley et al. 1995). In analysis of extinction probability for eight woodland species, the most important factor was either woodland area or the number of pairs breeding within the woodland (Bellamy et al. 1996b). However, isolation and local connectivity were also important in the probability of local extinction of a few species. For Blue Tit, probability of extinction was lower in woodlands with more hedges connected to the woodland (in one of two years analysed), for Chaffinch the length of hedgerow within $1 \mathrm{~km}$ was important (in both years), while for Great Tit the probability of local extinction was greater in more isolated woods (in one of two years analysed) (Bellamy et al. 1996b).

For three species of woodland bird (Great Spotted Woodpecker, Wood Nuthatch, Marsh Tit), presence at a scale of $10 \mathrm{~km} \times 10 \mathrm{~km}$ within England is primarily related to the amount of semi-natural and ancient woodland, but also to measures of fragmentation (Bailey et al. 2002). However, the use of a principal component approach in this study meant that effects of woodland isolation (e.g. mean distance to nearest ancient woodland) could not be distinguished from effects of connectivity (e.g. hedgerow density) and mean semi-natural woodland patch size. For 68 small woodlots in two agricultural landscapes in the Netherlands, the number of woodland bird species (those restricted to mature woods) 
was affected by isolation (inter-patch distance and distance to extensive woodland) while the total number of breeding bird species was not affected (Opdam et al. 1985). Across 235 small woodlots in the Netherlands (ranging from 0.1 to 39 ha), the number of woodland bird species was primarily related to wood area and secondarily to isolation variables, including amount of woodland area within the vicinity, distance to nearest large woodland and the density of wooded banks within $3 \mathrm{~km}$ (van Dorp \& Opdam 1987). However, species specific models for the incidence of woodland specialist birds generally showed effects of landscape composition (amount of woodland, distance to large woodland) but no effects of connectivity (density of wooded banks) (van Dorp \& Opdam 1987).

For invertebrate and plant species, targeted use of agri-environment measures and seminatural habitats is assumed to improve matrix permeability and reduce the functional isolation of woodland fragments (Watts et al. 2005a, Watts et al. 2005b). However, it is unclear to what extent this would also apply to woodland birds. Although a number of studies have considered effects of connectivity in terms of linear elements such as hedgerows or wooded banks, few have considered the broader question of whether the intensity of matrix landuse effects woodland bird dispersal and thus functional isolation. Walker et al. (2005) found green lanes, comprising double hedges that encompass an uncultivated trackway, supported greater species richness and abundance of birds than single hedgerows. Surrounding landuse affected bird occurrence on green lanes and both abundance and species richness were greater inside than outside green lanes. Although the influence of adjacent landuse on rates of dispersal were not examined, lower species richness and abundance can be assumed to reduce potential for connectivity.

Overall, there is thus some evidence that for some ubiquitous and edge species, connectivity between woodlands is important in rescuing populations, buffering against local extinction and favouring population synchrony. However, landscapes are generally more connected for habitat generalists than for habitat specialists (Dolman \& Fuller 2003) and the manner in which woodland specialists disperse requires further study. For woodland specialists, isolation is important; small woodlands have greater value if located near to existing large woodlands. However, direct buffering of existing large woods remains a better option.

\section{Within-site heterogeneity and configuration}

The simple dichotomy contrasting wooded patches in a sea of open habitat is intuitively appealing in terms of island biogeography or metapopulation dynamics. However, individual woodlands recognised at one scale contain internal patchy landscapes, with internal heterogeneity, structural patchiness, juxtaposition and configuration of elements. Examples arising by natural processes include natural treefalls, larger openings caused by disturbance that may be maintained as glades, but also patches of surviving trees within larger windfalls (Dolman \& Fuller 2003). In amenity woodlands or wooded parkland there may be a complex arrangement of patches of tree cover and open space, while in other 
managed woodlands structural patchiness can arise through planting composition, soil conditions, aspect, coppice panels or clear-fell coupes.

Such internal patchiness may have major consequences for habitat quality for woodland birds; the area, shape and arrangement of patches can affect suitability. For example, in coniferous plantations managed by clear-felling and restocking, Wood Lark density is greatest in young stands of 2-4 ha and decreases significantly in stands larger than 8 ha (Evans 2002). Conversely, Pied Flycatchers in mixed forest in Finland preferentially settle in larger forest stands; density is higher in stands greater than 1 ha while stands $<5$ ha are settled later and contain a higher proportion of unpaired males (Huhta et al. 1998). When individual patches are smaller than a territory, gap crossing during nest provisioning incurs costs that reduce habitat quality. A time and energy model for Great Tit showed that, with larger brood sizes or a high proportion of foraging trips involving gap-crossing, maximum sustainable daily energy expenditure would be exceeded if gaps were larger than 50-100 m (Hinsley 2000).

\section{Woodland configuration and edge effects}

Woodland size, configuration and internal heterogeneity lead to edge effects that can influence ecological processes and habitat quality. Here we briefly review some mechanisms that may be important in woodland birds.

There is a common presumption to regard edges as degraded habitats. However, edges may provide a valuable landscape element distinct from woodland interior. For example in Poland, edges of pine (Pinus sylvestris) forest adjacent to farmland support a third greater species richness than the forest interior (> $200 \mathrm{~m}$ from the edge) (Cieslak 1992). Species occurring at higher density at the edge included those normally associated with scrub and those feeding in open habitats outside the forest (e.g. Red-backed Shrike Lanius collurio, Yellowhammer, Common Starling Sturnus vulgaris), and also woodland species (Eurasian Golden Oriole Oriolus oriolus, Icterine Warbler, Spotted Flycatcher). In contrast, Common Chiffchaff and European Robin had higher densities in the forest interior. In coniferous plantations in the Belgian Ardennes, a greater number of species showed significant association with internal edges (Blackcap, Common Chiffchaff, Willow Warbler, Firecrest Regulus ignicapillus, European Robin, Winter Wren, Coal Tit, Hedge Accentor, Garden Warbler Sylvia borin, Tree Pipit, Great Spotted Woodpecker) than external edges (Great Tit, Common Wood Pigeon Columba palumbus, Common Blackbird, Carrion Crow Corvus corone, Blue Tit) while few were associated with interior forest (Goldcrest, Common Crossbill Loxia curvirostra) (Fautsch et al. 2003). In mixed deciduous old forest in Lithuania, higher bird densities occurred close to internal forest edges adjacent to clearcuts, with edge effects penetrating up to 90-120 $\mathrm{m}$ at mid-aged and old edges (Brazaitis et al. 2005). 
Access to open habitats abutting woodland is important to some species that show a preference for external edges. Athough the growth and structure of trees and shrubs at woodland edges (both external and around clearings) contrasts to that of interior habitats, we found very few studies that explicitly compared the structure of edge to interior in European woodlands. However, the expectation that deciduous forest edges form distinct, structurally complex, shrub habitats with greater shrub layer development is supported by studies of deer home range size (Saïd \& Servanty 2005). In north America, higher abundance of flycatchers and chickadees within $25 \mathrm{~m}$ of forest edge was attributed to well-developed foliage layers (Strelke \& Dickson 1980). Similarly, Marsh Tits benefit from a complex shrub layer (Hinsley \& Bellamy 2001). Flowering and fruiting may be greater in unshaded edge habitats than shaded interiors. For example, in montane pine forests of northeast lberia, cone abundance is greater on trees along forest edges than in forest interiors, resulting in larger Coal Tit group size (Brotons \& Herrando 2003). In Pennsylvania, autumn fruit availability is higher in mature forestagricultural edge and early successional shrub-sapling habitats than in mature forest interior, making these habitats important to migrating forest birds (Rodewald \& Brittingham 2004). Edge effects may result in higher abundance of arthropod prey. For example, both species richness and abundance of Neuroptera are greater at forest edges than interiors in Hungary, with $24 \%$ more species at steep edges and $60 \%$ more species at structurally rich edges compared to forest interior (Duelli et al. 2002).

As far as we are aware, the effect of adjacent landuse on the quality of woodland edge habitat for birds has not been studied in Britain.

\section{Edge effects and large herbivore impacts}

Patch configuration may mediate the impacts of large herbivores on habitat structure. In Britain, as elsewhere in Europe and north America, increasing numbers of native and introduced deer species are having a major impact on forest structure (Fuller \& Gill, 2001, Joys et al. 2004) with important consequences for woodland birds (Fuller \& Gill 2001). The arrangement of forest elements within the landscape may affect their suitability for deer; in particular the fragmentation of forests into small woodlands bordered by nutritious croplands is thought to contribute to the increase in deer numbers (Alverson et al. 1988, Sinclair 1997). This hypothesis has rarely been tested. In one study, conducted in a large lowland conifer plantation forest in eastern England $\left(200 \mathrm{~km}^{2}\right)$, Muntjac Muntiacus reevesi density (controlling for stand composition) was higher in woodland blocks (500-3500 ha) with a greater ratio of perimeter abutting open habitat, while no such relationship was found for Roe Deer Capreolus capreolus (Hemami et al. 2005).

\section{Edge effects and nest predation}

Work conducted in North America has shown increased rates of nest predation close to forest / farmland edges (Thompson, this issue). However, caution is advised in extending such findings to the 
UK. Effects of landscape structure on rates of nest predation vary among landscapes and regions and may also be species-specific (Lahti 2001). Furthermore, the behavioural response of a single predator species to landscape may differ between regions. For example, in North America Grey Squirrels Sciurus carolinensis are considered woodland specialists, but are landscape generalists in Britain. Similarly in Sweden the Eurasian Jay Garrulus glandarius is absent from small woodland fragments (Andrén 1992) but may be more ubiquitous in Britain. Few generalisations have emerged, though edge effects are found more frequently in landscapes with a high degree of forest fragmentation (Lahti 2001).

Compared to North America, relatively few European studies have considered landscape effects on nest predation. In Scandinavian mixed forests, nest predation rates for Pied Flycatcher were not related to stand area or distance to edge (Huhta et al. 1998). There is an urgent need for studies of edge effects within Britain, that compare nest predation rates in relation to landscape structure, patch size and across boundaries between woodland/farmland and woodland/semi-natural habitat. Landscape effects are hard to predict, on the one hand specialist predator species such as Weasel Mustela nivalis may be absent from smaller woods, whereas conversely generalist predators such as Hooded Crow Corvus cornix may operate more effectively in open/edge landscapes or small woodlands (Andrén 1992). Predation rates on artificial nests rarely match those for real nests and the contribution of different predator species can vary greatly (Burke et al. 2004, Moore \& Robinson 2004, Robinson et al. 2005, Thompson \& Burhans 2004), we strongly recommend that studies should monitor real nests and identify the predators involved.

\section{CONCLUSIONS AND RECOMMENDATIONS:}

In general, large woods support more species. Whilst generalist, matrix and edge species may occur in all woods, specialist woodland species such as Marsh Tit and Eurasian Treecreeper only occur regularly and in good numbers in larger woods (Table 5). However, smaller woods may be proportionately more valuable for a few edge species that benefit from access to open habitats, such as Hedge Accentor and Common Blackbird. For poorly dispersing species, such as Wood Nuthatch and also some generalists, woods must be close together for viable dispersal without mortality. There is evidence that hedgerows buffer woodland populations, but only for a few ubiquitous, generalist and edge species that have virtually continuous populations extending throughout the matrix. For poorly dispersing species, large core areas can sustain populations while the same area of woodland distributed across isolated fragments does not. The total area of habitat required to sustain a viable population is much less when configured in a network that includes one or more large, core patches.

Priority should be placed on protecting, managing, creating, expanding and buffering large woods and large core areas, but also in providing overall heterogeneity of wood sizes, including small woods. The quality of woodland habitat is of overwhelming importance and in most studies explains more variance than landscape scale effects. It is therefore important to promote old growth structures; but also young growth, scrub and internal edges. Heterogeneity of within-site structures should be 
provided, but not necessarily within the same site. It is more useful to provide woodland habitat heterogeneity within regions, than to attempt to provide a small amount of each habitat type within each woodland site.

Individual woods are more valuable in landscapes with a greater amount of wooded area, supporting an emphasis on regional woodland networks and aggregations. Woodland fragmentation has a very long history in the UK, while declines in woodland birds are more recent. However, agricultural intensification may have affected the quality and permeability of landscapes surrounding woodland fragments and the availability of semi-natural habitats that may buffer woodland bird populations.

This review has demonstrated that responses of an individual bird species to landscape structure can vary among regions, however, very few studies have examined the effects of landscape structure on woodland birds within the UK (findings summarised in Table 5). There is a need for further studies of the effects of woodland habitat quality, configuration, landscape composition and matrix structure for the viability and functional connectivity of woodland bird populations. There is also a need for further spatially explicit modelling of a wider range of species, to test alternative scenarios of strategic policy across a range of landscape types.

\section{REFERENCES}

Adriaensen, F., Chardon, J.P., De Blust, G., Swinnen, E., Villalba, S., Gulinck, H. \& Matthysen, E. 2003. The application of 'least-cost' modelling as a functional landscape model. Landscape Urban Plan. 64: 233-247.

Alderman, J., McCollin, D., Hinsley, S.A., Bellamy, P.E., Picton, P. \& Crockett, R. 2005. Modelling the effects of dispersal and landscape configuration on population distribution and viability in fragmented habitat. Landscape Ecol. 20: 857-870.

Allen, J.C., Schaffer, W.M. \& Rosko, D. 1993. Chaos reduces species extinction by amplifying local population noise. Nature 364: 229-232.

Alverson, W.S., Waller, D.M. \& Solheim, S.L. 1988. Forests too deer: edge effects in northern Wisconsin. Conserv. Biol. 2: 348-358.

Amar, A. \& Hewson, C. this issue. Recent changes in British woodland bird populations.

Andrén, H. 1992. Corvid density and nest predation in relation to forest fragmentation: a landscape perspective. Ecology 73: 794-804.

Andrén, H. 1994. Effects of habitat fragmentation on birds and mammals in landscapes with different proportions of suitable habitat: a review. Oikos 71: 355-366.

Anglestam, P. 1992.. Conservation of communities - the importance of edges, surroundings and landscape mosaic structure. In Hansson, L. (ed) Ecological Principles of Nature Conservation. Applications in Temperate and Boreal Environments. pp. 9-70. Elsevier Applied Science, London.

Bailey, S.-A., Haines-Young, R.H. \& Watkins, C. 2002. Species presence in framented landscapes: modelling of species requirements at the national level. Biol. Conserv. 108: 307-316.

Bellamy, P.E., Hinsley, S.A. \& Newton, I. 1996a. Factors influencing bird species numbers in small woods in south-east England. J. Appl. Ecol. 33: 249-262.

Bellamy, P.E., Hinsley, S.A. \& Newton, I. 1996b. Local extinctions and recolonisations of passerine bird populations in small woods. Oecologia 108: 64-71.

Bellamy, P.E., Brown, N.J., Hinsley, S.A., Enoksson, B., Firbank, L.G., Fuller, R.J., Hinsley, S.A. \& Schotman, A.G.M. 1998. The influences of habitat, landscape structure and climate on local distribution patterns of the nuthatch (Sitta europaea L.). Oecologia 115: 127-136. 
Bellamy, P.E., Rothery, P., Hinsley, S.A. \& Newton, I. 2000. Variation in the relationship between numbers of breeding pairs and woodland area for passerines in fragmented habitats. Ecography 23: 130-138.

Bellamy, P.E., Rothery, P. \& Hinsley, S.A. 2003. Synchrony of woodland bird populations: the effect of landscape structure. Ecography 26: 338-348.

Bennett, A.F., Hinsley, S.A., Bellamy, P.E., Swetnam, R.D. \& Mac Nally, R. 2004. Do regional gradients in land-use influence richness, composition and turnover of bird assemblages in small woods? Biol. Conserv. 119: 191-206.

Brazaitis, G., Petelis, K., Marozas, V., Roberge, J.-M. \& Angelstam, P. 2005. Age-related effects of clear-cut-old forest edges on bird communities in Lithuania. Scandinavian Journal of Forest Research, Supplement 20: 59-67.

Brotons, L. \& Herrando, S. 2003. Effect of increased food abundance near forest edges on flocking patterns of Coal Tit Parus ater winter groups in mountain coniferous forests. Bird Study 50: 106111.

Burke, D.M., Elliott, K., Moore, L., Dunford, W., Nol, E., Phillips, J., Holmes, S. \& Freemark, K. 2004. Patterns of nest predation on artificial and natural nests in forests. Conserv. Biol. 18: 381 388.

Chardon, J.P., Adriaensen, F. \& Matthysen, E. 2003. Incorporating landscape elements into a connectivity measure: a case study for the speckled wood butterfly (Pararge aegeria L.). Landscape Ecol. 18: 561-573.

Cieslak, M. 1985. Influence of forest size and other factors on breeding bird species number. Ekol. Pol Pol. J. Ecol 33: 103-121.

Cieslak, M. 1992. Breeding bird communities on forest edge and interior. Ekol. Pol. - Pol J Ecol. 40: $461-475$

Day, A. 1989. Upland Vegetation Survey 1979-1989: Background Methodology and Summary of Data Collected. Nature Conservancy Council, Bangor.

Defra 2006. England's Trees, Woods and Forests: a Consultation Document. Department for Environment Food and Rural Affairs, London.

Dolman, P.M. \& Fuller, R.J. 2003. The processes of species colonisation in wooded landscapes: a review of principles. In Humphrey, J., Newton, A., Latham, J., Gray, H., Kirby, K.H., Poulsom, E. \& Quine, C. (eds.) The Restoration of Wooded Landscapes pp. 25-36. Forestry Commission, Edinburgh.

Duelli, P., Obrist, M.K. \& Flückiger, P.F. 2002. Forest edges are biodiversity hotspots - Also for Neuroptera. Acta Zoologica Academiae Scientiarum Hungaricae 48: 75-87.

Dunning, J.B., Danielson, B.J. \& Pulliam, H.R. 1992. Ecological processes that affect populations in complex landscapes. Oikos 65: 169-175.

Evans, M.D. 2002. GIS-based Modelling of Woodlark (Lullula arborea) and Nightjar (Caprimulgus europaeus) Habitats in a Forested Landscape. Ph.D., University of East Anglia, Norwich.

Fautsch, M., Delvingt, W. \& Paquet, J.-Y. 2003. Influence of woodland edge structure on bird communities in the Belgian Ardennes [L'influence de la structure des lisières forestie?res sur leur capacite? d'accueil pour l'avifaune dans l'Ardenne Belge]. Alauda 71: 253-260.

Forestry Commission 2005. Keepers Of Time: A Statement of Policy for England's Ancient and Native Woodland. Forestry Commission, Cambridge.

Fuller, R.J. \& Gill, R.M.A. 2001. Ecological impacts of increasing numbers of deer in British woodland. Forestry 74: 193-199.

Haines-Young, R.H., Barr, C.J., Black, H.I.J., Briggs, D.J., Bunce, R.G.H., Clarke, R.T., Cooper, A., Dawson, F.H., Firbank, L.G., Fuller, R.M., Furse, M.T., Gillespie, M.K., Hill, R., Hornung, M., Howard, D.C., McCann, T., Morecroft, M.D., Petit, S., Sier, A.R.J., Smart, S.M., Smith, G.M., Stott, A.P., Stuart, R.C. \& Watkins, J.W. 2000. Accounting for Nature: Assessing Habitats in the UK Countryside. DETR, London.

Hampson, A.M. \& Peterken, G.F. 1998. Enhancing the biodiversity of Scotland's forest resource through the development of a network of forest habitats. Biodivers. Conserv. 7: 179-192.

Hanski, I. 1998. Metapopulation dynamics. Nature 396: 41-49.

Hanski, I. 1999. Metapopulation ecology Oxford University Press, Oxford.

Hanski, I. \& Ovaskainen, O. 2000. The metapopulation capacity of a fragmented landscape. Nature 404: 755-758. 
Hanski, I., Moilanen, A. \& Gyllenberg, M. 1996. Minimum viable metapopulation size. Am. Nat. 147: 527-541.

Harrison, S. 1994. Metapopulations and conservation. In Edwards, P.J., May, R.M. \& Webb, N.R. (eds) Large-Scale Ecology and Conservation Biology pp. 111-128. Blackwell Scientific Publications, Oxford.

Heino, M., Kairala, V., Ranta, E. \& Londström, J. 1997. Synchronous dynamics and rates of extinction in spatially structured populations. P. Roy. Soc. - B Biol. Sci. 264: 481-486.

Hemami, M.R., Watkinson, A.R. \& Dolman, P.M. 2005. Population densities and habitat associations of introduced muntjac Muntiacus reevesi and native roe deer Capreolus capreolus in a lowland pine forest. Forest Ecology and Management. For. Ecol. Manag. 215: 224-238.

Hinsley, S.A. 2000. The costs of multiple patch use by birds. Landscape Ecol. 15: 765-775.

Hinsley, S.A. \& Bellamy, P.E. 2001. The influence of hedge structure, management and landscape context on the value of hedgerows to birds: A review. J. Environ. Manage. 60: 33-49.

Hinsley, S.A., Bellamy, P.E. \& Newton, I. 1995a. Bird species turnover and stochastic extinction in woodland fragments. Ecography 18: 41-50.

Hinsley, S.A., Bellamy, P.E., Newton, I. \& Sparks, T.H. 1995. Habitat and landscape factors influencing presence of individual breeding bird species in woodland fragments. J. Avian Biol. 26: 94-104.

Hinsley, S.A., Bellamy, P.E., Newton, I. \& Sparks, T.H. 1996. Influences of population size and woodland area on bird species distributions in small woods. Oecologia 105: 100-106.

Hinsley, S.A., Bellamy, P.E., Enoksson, B., Fry, G., Gabrielsen, L., McCollin, D. \& Schotman, A. 1998. Geographical and land-use influences on bird species richness in small woods in agricultural landscapes. Global Ecol. Biogeogr. 7: 125-135.

Hinsley, S.A., Rothery, P. \& Bellamy, P.E. 1999. Influence of woodland area on breeding success in Great Tits Parus major and Blue Tits Parus caeruleus. J. Avian Biol. 30: 271-281.

Howe, E.A. \& Blackstock, T.H. 1991. Supplementary Notes for Phase 1 Survey in Wales. CCW, Bangor

Huhta, E., Rahko, P. \& Jokimäki, J. 1998. Distribution and reproductive success of the pied flycatcher Ficedula hypoleuca in relation to forest patch size and vegetation characteristics; the effect of scale. Ibis 140: 214-222.

Joys, A.C., Fuller, R.J. \& Dolman, P.M. 2004. Influences of deer browsing, coppice history and standard trees on the growth and development of vegetation structure in coppiced woods in lowland England. For. Ecol. Manag. 202: 23-37.

Kurki, S., Nikula, A., Helle, P. \& Lindén, H. 2000. Landscape fragmentation and forest composition effects on grouse breeding success in boreal forests. Ecology 81: 1985-1997.

Lahti, D.C. 2001. The "edge effect on nest predation" hypothesis after twenty years. Biol. Conserv. 99: 365-374.

Laurance, W.F. 1991. Ecological correlates of extinction processes in Australian tropical rain forest mammals. Conserv. Biol. 5: 79-89.

Mason, W. this issue. Changes in the management of British forests and future trends.

McCollin, D. 1993. Avian distribution patterns in a fragmented wooded landscape (North Humberside, UK): the role of between-patch and within-patch structure. Global Ecol. Biogeogr. 3: 48-62.

Moore, R.P. \& Robinson, W.D. 2004. Artificial bird nests, external validity, and bias in ecological field studies. Ecology 85: 1562-1567.

Opdam, P., Rijsdijk, G. \& Hustings, F. 1985. Bird communities in small woods in an agricultural landscape: Effects of area and isolation. Biol. Conserv. 34: 333-352.

Paradis, E., Baillie, S.R., Gregory, R.D. \& Sutherland, W.J. 1998. Patterns of natal and breeding dispersal in birds. J. Anim. Ecol. 67: 518-536.

Paradis, E., Baillie, S.R., Gregory, R.D. \& Sutherland, W.J. 1999. Dispersal and spatial scale affect synchrony in spatial population dynamics. Ecol. Lett. 2: 114-120.

Paradis, E., Baillie, S.R. \& Sutherland, W.J. 2002. Modeling large-scale dispersal distances. Ecol. Model. 151: 279-292.

Peterken, G.F. 2000. Rebuilding networks of forest habitats in lowland England. Landscape Res. 25: 291-303.

Peterken, G.F. 2002. Reversing the Habitat Fragmentation of British Woodlands. WWF-UK, Godalming, Surrey. 
Peterken, G.F. 2003. Developing forest habitat networks in Scotland. In Humphrey, J., Newton, A., Latham, J., Gray, H., Kirby, K.H., Poulsom, E. \& Quine, C. (eds) The Restoration of Wooded Landscapes pp. 85-91. Forestry Commission, Edinburgh.

Peterken, G.F., Baldock, D. \& Hamspon, A. 1995. A Forest Habitat Network for Scotland., Rep. No. 44. Scottish Natural Heritage, Edinburgh.

Rackham, O. 1986. The History of the Countryside J.M. Dent, London.

Reijnen, R., Harms, W.B., Foppen, R.P.B., de Visser, R. \& Wolfert, H.P. 1995. Rhine-Econet. Ecological Networks in River Rehabilitation Scenarios: a Case Study for the Lower Rhine., Rep. No. 58. RIZA, Institute for Inland Water Management and Waste Water Treatment, Lelystad.

Riddington, R. \& Gosler, A.G. 1995. Differences in reproductive success and parental quality between habitats in the Great Tit Parus major. Ibis 137: 371-378.

Robinson, W.D., Styrsky, J.N. \& Brawn, J.D. 2005. Are artificial bird nests effective surrogates for estimating predation on real bird nests? A test with tropical birds. Auk 122: 843-852.

Rodewald, P.G. \& Brittingham, M.C. 2004. Stopover habitats of landbirds during fall: Use of edgedominated and early-successional forests. Auk 121: 1040-1055.

Rolstad, J. \& Wegge, P. 1987. Distribution and size of capercaillie leks in relation to old forest fragmentation. Oecologia 72: 389-394.

Saccheri, I., Kuussaari, M., Kankare, M., Vikman, P., Fortelius, W. \& Hanski, I. 1998. Inbreeding and extinction in a butterfly metapopulation. Nature 392: 491-494.

Saïd, S. \& Servanty, S. 2005. The influence of landscape structure on female roe deer home-range size. Landscape Ecol. 20: 1003-1012.

Sinclair, A.R.E. 1997. Carrying capacity and the overabundance of deer. In McShea, J., Underwood, H.B. \& Rappole, H. (eds) The Science of Overabundance: Deer Ecology and Population Management pp. 380-394. Smithsonian Institution, Washington.

Strelke, W.K. \& Dickson, J.G. 1980. Effect of forest clear-cut edge on breeding birds in east Texas. J. Wildlife Manage. 44: 559-567.

Sutherland, W.J., Pullin, A.S., Dolman, P.M. \& Knight, T.M. 2004. The need for evidence-based conservation. Trends Ecol. Evol. 19: 305-308.

Thompson, F. this issue. Predation, habitat selection, avian populations and community structure - a North American perspective. Ibis

Thompson, F.R.I. \& Burhans, D.E. 2004. Differences in predators of artificial and real songbird nests: Evidence of bias in artificial nest studies. Conserv. Biol. 18: 373-380.

Tilman, D., May, R.M., Lehman, C.L. \& Nowak, M.A. 1994. Habitat destruction and the extinction debt. Nature 371: 65-66.

van Dorp, J. \& Opdam, P.F.M. 1987. Effects of patch size, isolation and regional abundance on forest bird communities. Landscape Ecol. 1: 59-73.

Verboom, J., Foppen, R., Chardon, P., Opdam, P. \& Luttikhuizen, P. 2001. Introducing the key patch approach for habitat networks with persistent populations: an example for marshland birds. Biol. Conserv. 100: 89-101.

Verhulst, S., Perrins, C.M. \& Riddington, R. 1997. Natal dispersal of Great Tits in a patchy environment. Ecology 78: 864-872.

Villard, M., Trzcinkski, M.K. \& Merriam, G. 1999. Fragmentation effects on forest birds: relative influence of woodland cover and configuration on landscape occupancy. Conserv. Biol. 13: 774783.

Walker, M.P., Dover, J.W., Hinsley, S.A. \& Sparks, T.H. 2005. Birds and green lanes: Breeding season bird abundance, territories and species richness. Biol. Conserv. 126: 540-547.

Watts, K., Griffiths, M., Quine, C., Ray, D. \& Humphrey, J.W. 2005a. Towards a Woodland Habitat Network for Wales. Contract Science Report No.686 Countryside Council for Wales, Bangor.

Watts, K., Humphrey, J.W., Griffiths, M., Quine, C. \& Ray, D. 2005b. Evaluating Biodiversity in Fragmented Landscapes: Principles. Forestry Commission Information Note No.073 Forestry Commission, Edinburgh.

Wiens, J.A. 1994. Habitat fragmentation: island v landscape perspectives on bird conservation. Ibis 137: $97-104$.

Woodland Trust 2002. Space for Nature: Landscape-Scale Action for Woodland Biodiversity. The Woodland Trust. 
Table 1. Species contributing most to turnover differ between small (c. 1 ha, $n=24)$ and large (c. 6 ha, $n=16$ ) woods. Species are ranked in order of their contribution to total turnover and hence some species have the same ranking; * species whose turnover rate is affected by shooting and other management. From (Hinsley et al. 1995a).

\begin{tabular}{|l|l|}
\hline Small woods & Large woods \\
\hline${ }^{*}$ Common Pheasant Phasianus colchicus & 1. Great Spotted Woodpecker \\
\hline 1. Hedge Accentor & ${ }^{*}$ Carrion Crow \\
\hline 2. Blue Tit & 2. Marsh Tit \\
\hline 3. Winter Wren & 2. Sparrowhawk \\
\hline 3. European Robin & 3. Long-tailed Tit \\
\hline 3. Song Thrush & 3. Stock Pigeon Columba oenas \\
\hline${ }^{*}$ Carrion Crow & ${ }^{*}$ Black-billed Magpie Pica pica \\
\hline * Red-legged Partridge Alectoris rufa & ${ }^{*}$ Red-legged Partridge \\
\hline 4. Great Tit & 4. Common Bullfinch Pyrrhula pyrrhula \\
\hline
\end{tabular}

Table 2. Relationship of abundance to woodland area for eight species recorded annually over eight years in 53-160 woods (up to 10 ha). Mean and standard error of the slope parameter, $b$, are shown: $b$ $<1$ indicates density is higher in small woods, for $b=1$ numbers increase in proportion to area, for $b>1$ density is higher in larger woods. From (Bellamy et al. 2000).

\begin{tabular}{|l|l|}
\hline Species & $\boldsymbol{b} \pm$ se \\
\hline Hedge Accentor & $0.52 \pm 0.02$ \\
\hline Common Blackbird & $0.52 \pm 0.01$ \\
\hline Chaffinch & $0.62 \pm 0.01$ \\
\hline Blue Tit & $0.75 \pm 0.02$ \\
\hline Winter Wren & $0.75 \pm 0.02$ \\
\hline Great Tit & $0.77 \pm 0.04$ \\
\hline European Robin & $0.80 \pm 0.02$ \\
\hline Long-tailed Tit & $1.32 \pm 0.11$ \\
\hline
\end{tabular}


Table 3. Reproductive performance of Blue Tit and Great Tit in small (1 ha) versus large (150 ha) woods predicted from a multiple regression of performance measures against woodland area. From (Hinsley et al. 1999).

\begin{tabular}{|l|l|l|}
\hline Parameter & Great Tit & Blue Tit \\
\hline timing of breeding & 7 days later & 8 days later \\
\hline clutch size & same & same \\
\hline $\begin{array}{l}\text { no. young at 11 days } \\
\text { mean body mass of } \\
\text { young at ...days (g) }\end{array}$ & -1.2 & -1.8 \\
\hline $\begin{array}{l}\text { total brood mass at } \\
\text {...days (g) }\end{array}$ & -30.0 & same \\
\hline no. fledged & -1.4 & -22.5 \\
\hline
\end{tabular}

Table 4. Effects on population viability of adding different configurations of woodland to a Wood Nuthatch metapopulation in a sparsely wooded landscape. A spatially explicit population model incorporates demographic stochasticity, sedentary territorial adults, random post-natal dispersal assuming a $2 \mathrm{~km}$ 'perceptual range' that results in either emigration, mortality or settlement of vacant territories, in a grided landscape of $200 \times 200$ 1ha cells with a non-wooded matrix and wooded patches comprising both suitable and unsuitable habitat. From (Alderman et al. 2005).

\begin{tabular}{|l|l|l|}
\hline Scenario & $\begin{array}{l}\text { Buffer (additional area of } \\
\text { suitable habitat created) }\end{array}$ & Population outcome \\
\hline $\begin{array}{l}\text { current landscape } \\
(n=248 \text { woods, total 298 ha, })\end{array}$ & +0 & not sustained (extinction) \\
\hline $\begin{array}{l}\text { buffer all smaller woods }(n= \\
242)\end{array}$ & +801 ha & not sustained \\
\hline buffer six largest woods & +275 ha & sustained \\
\hline buffer largest wood only & $+40-60$ ha & sustained \\
\hline
\end{tabular}


Table 5. Summary of landscape effects detected in studies of British woodland birds. Edge:

preferentially associated with woodland edges or show preference for small rather than large woodland patches; Small patch: ubiquitous and commonly occur in woodland patches < 10 ha; Large patch: only reach high probability of occurrence in woodland patches $>10$ ha; Dispersal limited: species for which limited dispersal ability reduces probability of occurrence or strength of local population synchrony; Connectivity: species that respond positively to increased connectivity, with greater probability of colonisation, lower extinction probability or greater degree of local population synchrony; Fragmentation sensitive: species that have greater probability of occurrence in woodlands situated in landscapes with a greater proportion of woodland cover.

\section{Species}

Blackcap

Blue Tit

Chaffinch

Common Blackbird

Common Bullfinch

Common Chiffchaff

Common Redstart

Coal Tit

Eurasian Sparrowhawk

Eurasian Treecreeper

European Robin

Great Spotted

Woodpecker

Great Tit

Hawfinch

Hedge Accentor

Long-tailed Tit

Marsh Tit

Tree Pipit

Song Thrush

Spotted Flycatcher

Stock Pigeon

Willow Warbler

Winter Wren

Wood Nuthatch

\section{Edge Small \\ patch \\ Large Dispersal \\ patch limited
Connectivity Fragmentation sensitive

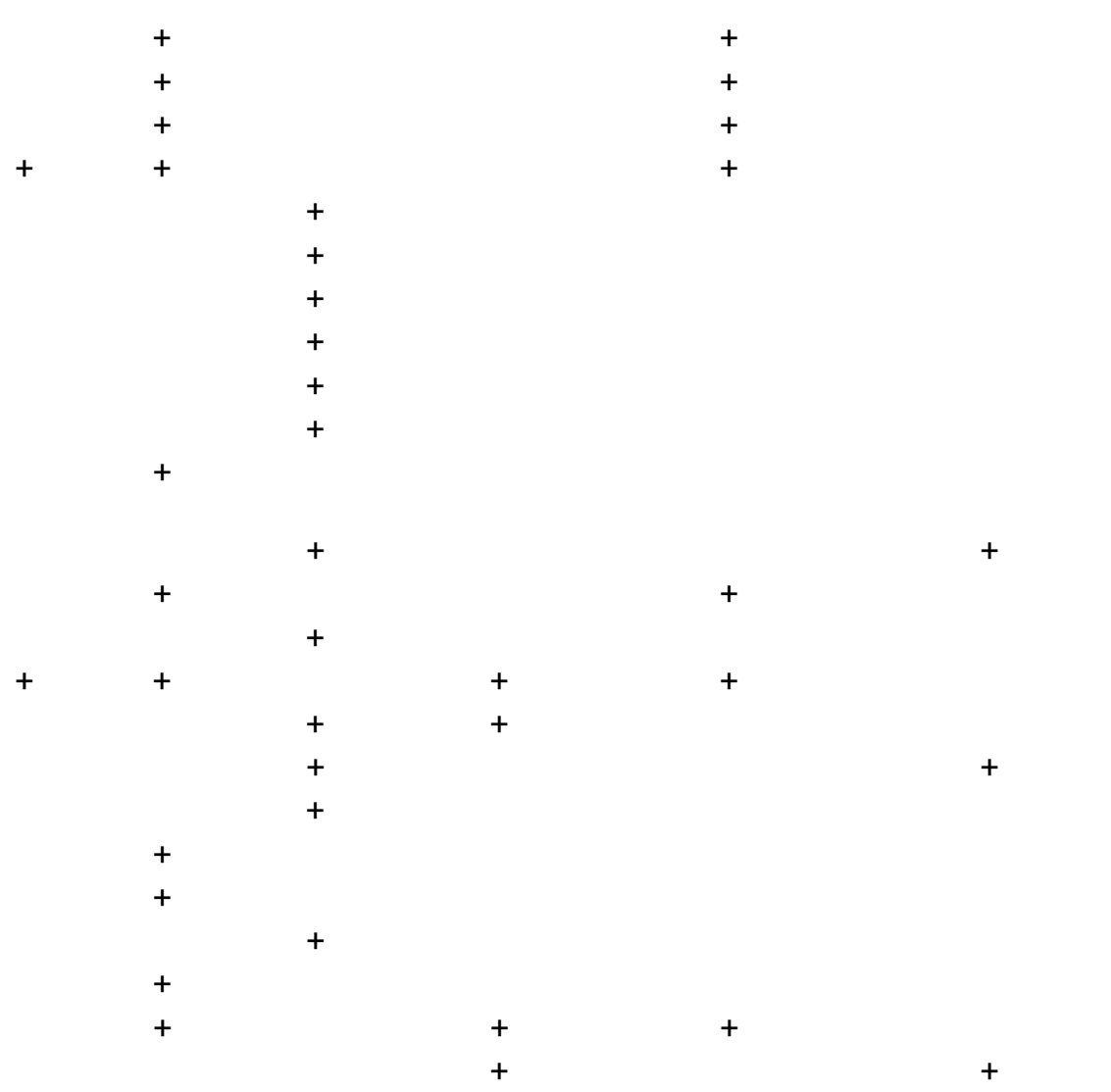


Figure 1. Woodland network defined for a generic woodland species with good dispersal for an area of western Wales (redrawn from Watts et al. 2005a). (a) landcover data, used to define both (b) existing patches of broadleaved woodland and (c) a cost surface for dispersal within matrix habitats, with high impedence (dark colours) assigned to intensive habitat types (e.g. improved grassland, arable), intermediate costs in semi-natural habitats (e.g. heathland, unimproved grassland) and low cost of movement (light colours) in habitats with strong three dimensional structure (e.g. semi-natural scrub, bracken); (d) resulting woodland network, with existing woodland patches in dark green and network shaded. Here, individuals dispersing from the woodland patches may potentially colonise new woodland created within the same network.

a
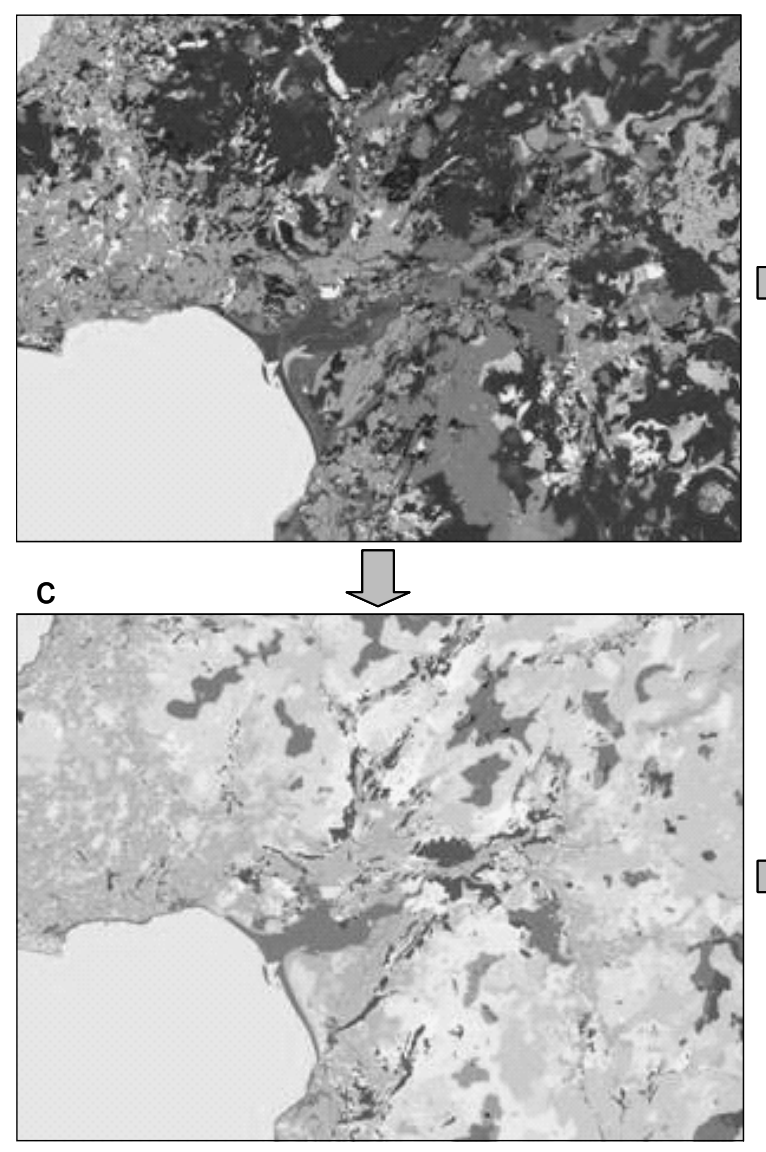

b

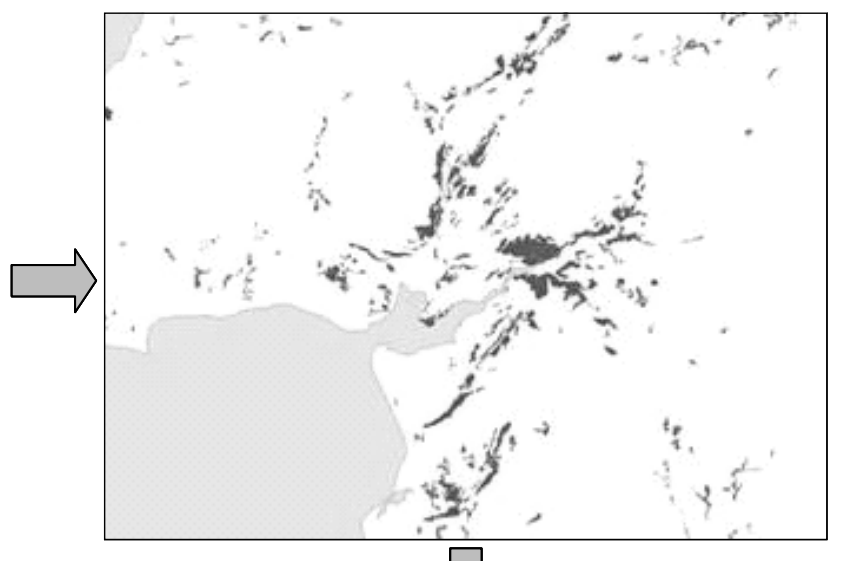

d

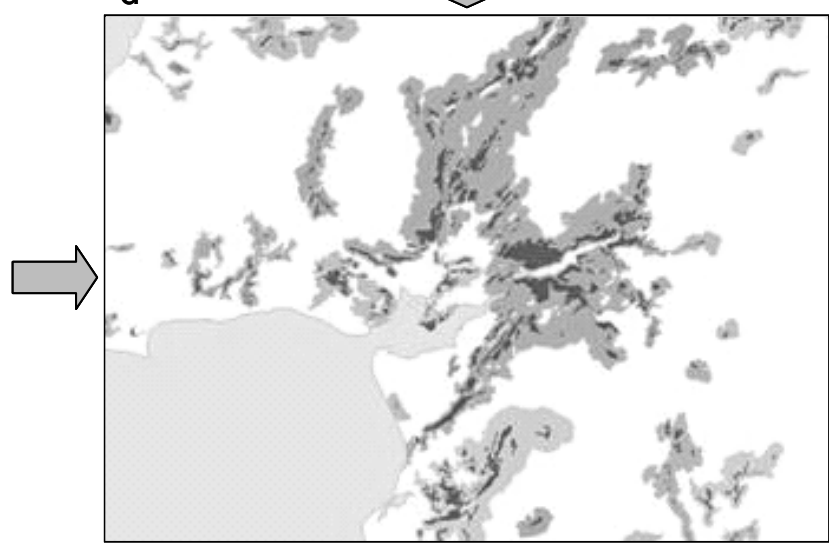


Figure 2. Species richness of (a) all birds (open circles) and breeding birds (closed circles) in relation to fragment area and (b) annual rates of species turnover (numbers of species extinctions plus colonisations), for a sparsely wooded region of Cambridgeshire. Redrawn from a) Bellamy et al. (1996a) and b) Hinsley et al. (1995).

(a)

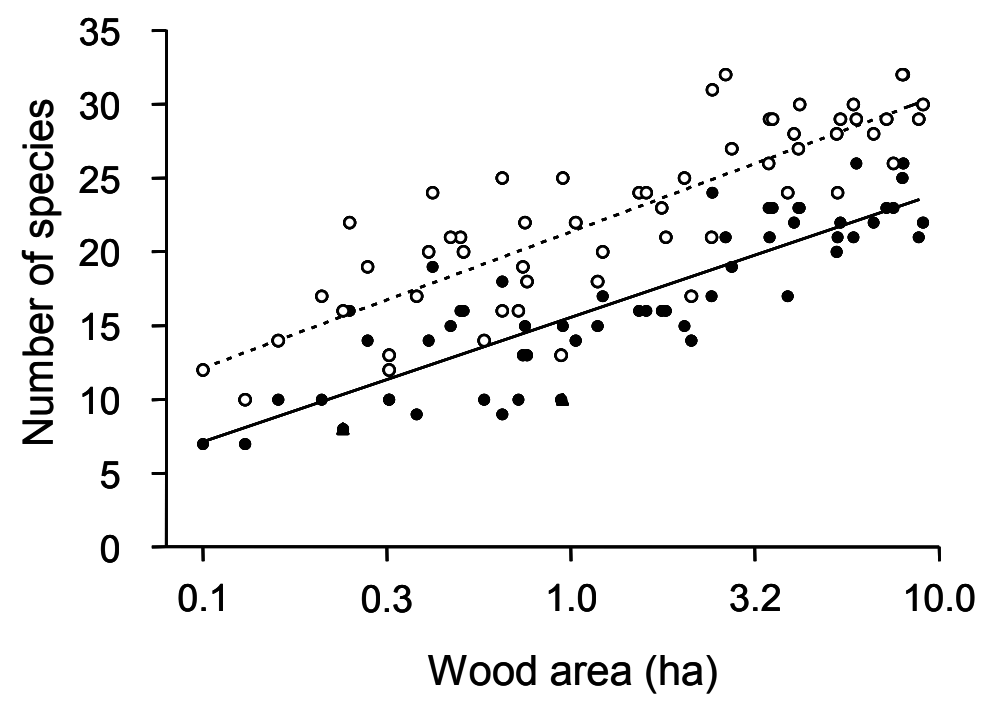

(b)

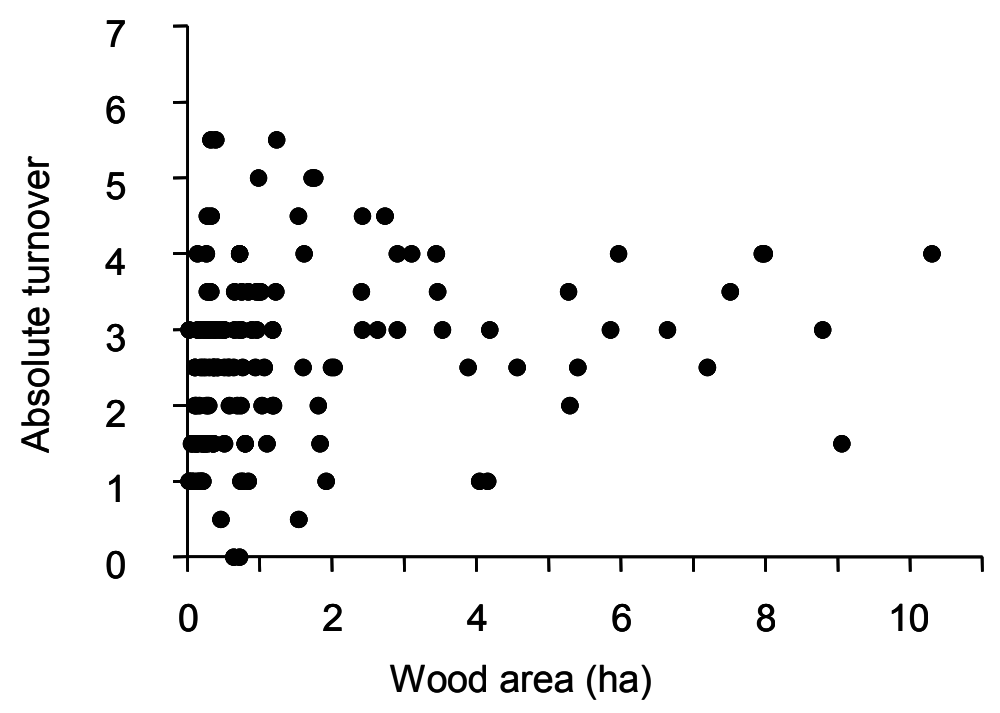


Figure 3. Probability of breeding in relation to woodland area, calculated by logistic regression for data from 151 woods (0.02-30.0 ha) censused over three years. Redrawn from Hinsley et al. (1996).

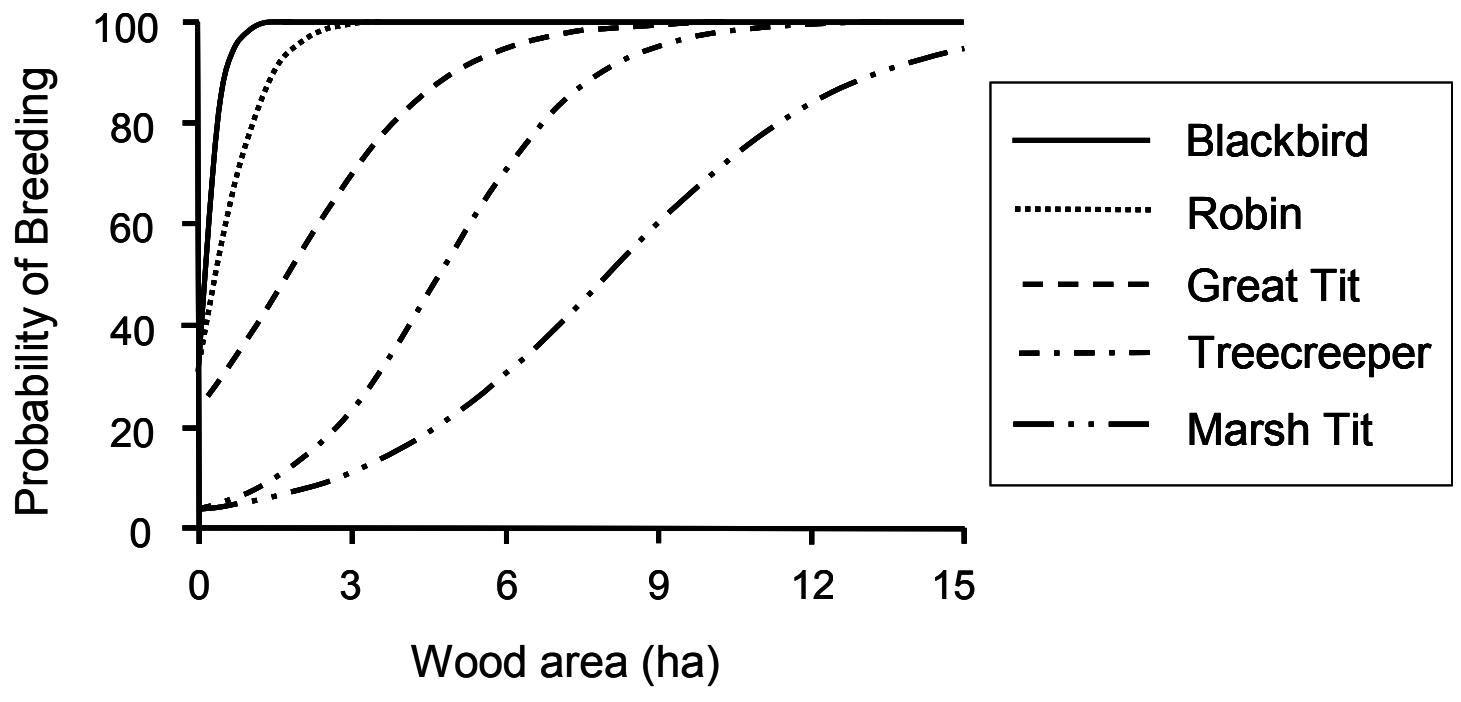


Figure 4. Dispersal distances $(\mathrm{km})$ of 28 woodland birds, taken from Paradis et al. (1998). For each species the mean (a measure of the peak dispersal distance) and standard deviation (a measure of the tail of the distribution) of natal dispersal recorded from ringing data of the British Trust for Ornithology are shown. Species codes: B. Common Blackbird; BC Blackcap; BF Common Bullfinch; BT Blue Tit; C. Carrion Crow; CC Common Chiffchaff; CH Chaffinch; CT Coal Tit D. Hedge Accentor; G. Green Woodpecker; GR Greenfinch; GS Great Spotted Woodpecker; GT Great Tit; J. Eurasian Jay; LT Longtailed Tit; M. Mistle Thrush; MG Black-billed Magpie; NH Wood Nuthatch; PF Pied Flycatcher; R. European Robin; RT Common Redstart; SG Common Starling; SH Eurasian Sparrowhawk; ST Song Thrush; TO Tawny Owl; WH Whitethroat; WR Winter Wren; WT Willow Tit

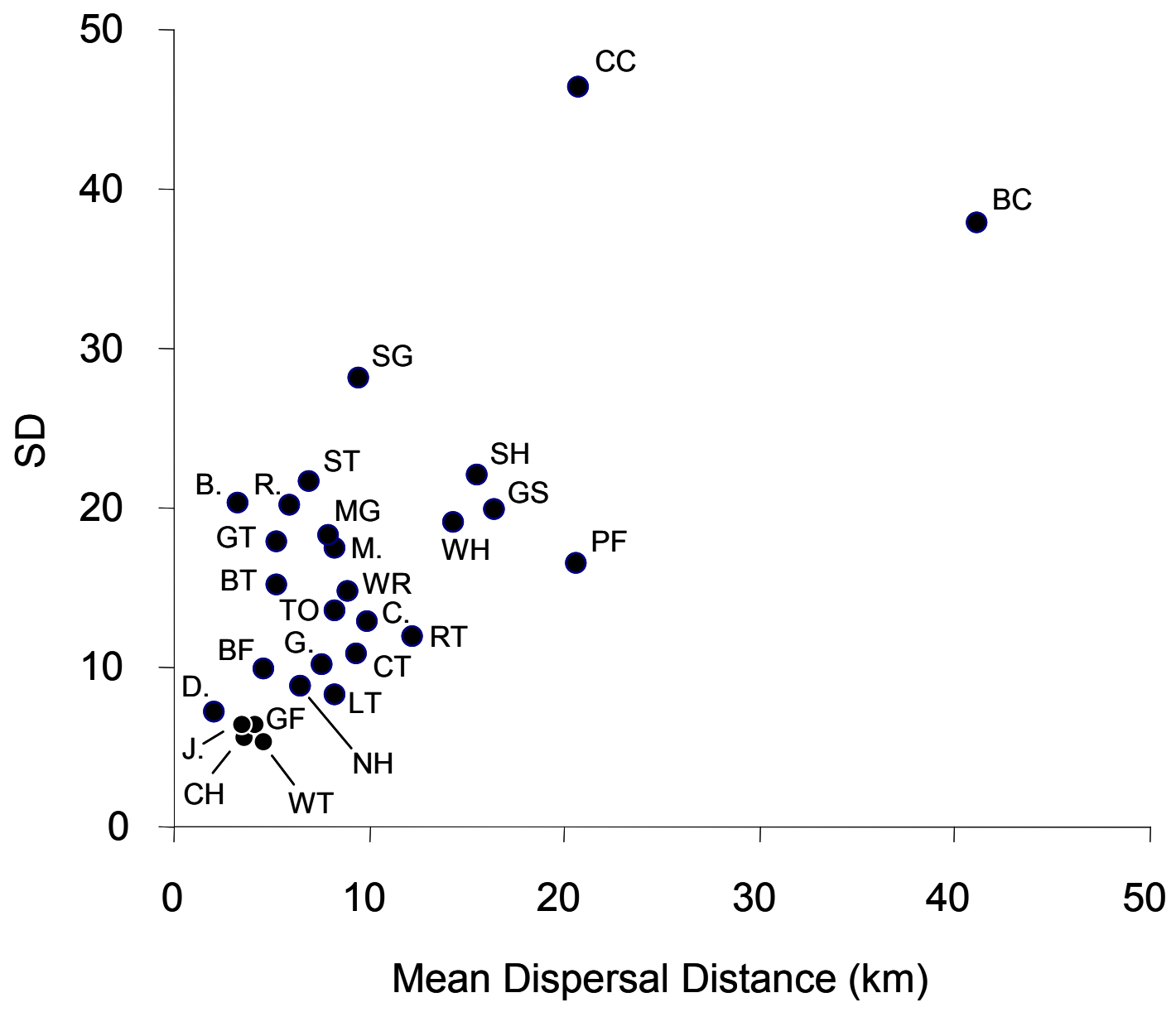

